\title{
Sustainable Age and Ageing (SAaA) - An Interdisciplinary Theoretical Model of Successful Age and Ageing
}

\author{
Christiane Bahr \\ Private Practice for Psychotherapy and Supervision \\ Erzabt-Klotz-Street 9 \\ Salzburg, Austria
}

\begin{abstract}
This interdisciplinary theory of age and ageing with strong educational and psychological impact combines issues of human age and ageing with various topics of sustainability and sustainable development. Both topics are essential for humane, fair and ecologically prosperous future perspectives and are well matched. The model postulates that it is not only of current interest to bring these issues together, but also essential for the planet's survival and people's quality of life, especially in old age. This positive, sensible and wise way is assumed to be relevant for individuals and societies alike. Three main theses are considered: 1) Sustainable societal inclusion of elderly people and their competencies is essential and relevant to the whole of society; 2) Lifelong learning is a chance for sustainability and mature sustainable living and engagement; 3) The person-centred approach is helpful in supporting sustainable development and in empowering elderly people in diverse contexts. - The percipience, awareness and endorsement of elderly people's wide interests, varied potentials and matured wisdom are thus important milestones. They contribute enormously to the creation of sustainable lifestyles for themselves, society and (other) countries too. This is demonstrated by a proposed institution named SAI, the short form for "Sustainable Age and Ageing Initiative".
\end{abstract}

\section{Introduction}

Successful age and ageing is multidimensional; this provides challenges involving many disciplines, such as educational science, psychology, biology, sociology, medical sciences and many others alike, and so does sustainability in relation to many sectors. Both topics are broad and comparably trendsetting.

This new "Model of Sustainable Age and Ageing" is therefore being described as an interdisciplinary concept of successful age and ageing which offers a theoretical framework to explain good age and ageing for individuals and people(s) alike. It achieves this by considering subjective and objective personal, regional and worldwide issues in different societies and traditions. - Thus this concept can be assigned and applied in various scientific fields, such as educational science, psychology, sociology, biology and social medicine as well as general business administration and general business management, economics, theology, future science and beyond. - Wherever scientists or practitioners try to bring these two issues together, the use of this new conceptual model, its theses and principles, may help them to find inspiration through this instrumental theoretical framework. It may support further constructive and continuative knowledge and thoughts and strengthen good ideas to favour the quality of life for all living beings on earth and elderly persons in particular. In the long term this may hopefully serve for the benefit of our planet's survival and lead to a better ecological continuity of life on earth. - This "Model of Sustainable Age and Ageing" refers not only to European or Western issues and standards however, but applies in form and content to a wide and interdisciplinary global range. Yet, in view of its restricted length this article now focuses on explanations concerning centralEuropean and mainly socially oriented circumstances only. For further insights and perspectives concerning this challenging, empirically based theoretical model, interested persons are kindly asked to look for existing and future publications by this author.

\section{Sustainable Living - Sustainability and Sustainable Development}

We are currently living in a thought-provoking period of transition. Impressive pictures and reports show how, extraordinarily, many human beings in different countries and environments all over the world are surviving to great old age. As far as we know, this has never happened before in the history of mankind. Never before have so many people been able to reach old age with further good life expectancy as these days and this is especially true for Central-Europe. Furthermore, never before have as many elderly people as at present been able to continually and actively participate in society and contribute socially. This is due to their valuable experience and wisdom as well as to multiple 
possibilities in terms of networking and financial options.

Unfortunately, there also exists another side and reality of present living on earth which is rather devastating.

And this has of course to do with global unfairness and injustice. - As the Global Footprint Network highlighted we have just passed Earth Overshoot Day again [8]. This year, from the $19^{\text {th }}$ of August onwards we are living at the expense of future generations and using their resources on earth, since we would need 1.5 planets to cover the present consumption of energy and resources on earth nowadays. Moreover, some people in specific regions and countries live - in an extraordinarily alarming way - on the resources and opportunities of other people(s) who are jet not even able to meet their basic needs for living. - Unrestrained spending and unfair consumption on the part of such privileged individuals, groups and nations can thus exacerbate this dramatic situation in terms of wrongfulness and inequity. While people on the one side actually take too much for themselves, others suffer from hunger and thirst, and are starving and dying. Abundance and mercilessness are happening at the same time and this mostly but not always, in different places. We live within this reality on earth all the time and meanwhile unfortunately also reach the Earth Overshoot Day every year. - Consequently, we must learn how to deal with it and hopefully adapt our behaviour individually and internationally. Adapt in terms of an active increase of perception of fair consumption, human rights and dignity for everybody on this planet and last but not least, more environmental sense and responsibility. And the increasing number of elderly people, looking for good ways of living, could make a cutting-edge as well as big difference and change in this respect.

Much has been done in terms of defining and implementing initiatives and projects of sustainability and sustainable development and living in the last 20 years. It will therefore be taken for granted, that these widely accepted definitions and engagements are generally understood [19] [20] [17] [14]. But for those who have not yet had the chance to hear about this important theme, the following may be mentioned: issues of concern, highlights and arguments, as stated on the part of the United Nations, can be found at "commitments in the Rio+20 outcome document 'The Future We Want' Agenda 21, the Programme for the Further Implementation of Agenda 21 or the Johannesburg Plan of Implementation of the World Summit on Sustainable Development" [18, p. 2].

Consequently, in the present "Model of Sustainable Age and Ageing" the seventeen goals which have been formulated as part of the "Open Working Group on Sustainable Development Goals" [19] on behalf of the United Nations (Sustainable
Development Knowledge Platform) are also valid for this theory and should therefore be brought together and considered throughout my three theses. You will find these seventeen "Sustainable Development Goals" in the enclosed table.

\section{Table 1. "Sustainable Development Goals" on behalf of the United Nations [19, p. 5]}

\begin{tabular}{|c|c|}
\hline GOALS & "Sustainable Development Goals" \\
\hline "Goal 01 & End poverty in all its forms everywhere \\
\hline Goal 02 & $\begin{array}{l}\text { End hunger, achieve food security and } \\
\text { improved nutrition, and promote } \\
\text { sustainable agriculture }\end{array}$ \\
\hline Goal 03 & $\begin{array}{l}\text { Ensure healthy lives and promote well- } \\
\text { being for all[,] at all ages }\end{array}$ \\
\hline Goal 04 & $\begin{array}{l}\text { Ensure inclusive and equitable quality } \\
\text { education and promote life-long learning } \\
\text { opportunities for all }\end{array}$ \\
\hline Goal 05 & $\begin{array}{l}\text { Achieve gender equality and empower all } \\
\text { women and girls }\end{array}$ \\
\hline Goal 06 & $\begin{array}{l}\text { Ensure availability and sustainable } \\
\text { management of water and sanitation for all }\end{array}$ \\
\hline Goal 07 & $\begin{array}{l}\text { Ensure access to affordable, reliable, } \\
\text { sustainable, and modern energy for all }\end{array}$ \\
\hline Goal 08 & $\begin{array}{l}\text { Promote sustained, inclusive and } \\
\text { sustainable economic growth, full and } \\
\text { productive employment and decent work } \\
\text { for all }\end{array}$ \\
\hline Goal 09 & $\begin{array}{l}\text { Build resilient infrastructure, promote } \\
\text { inclusive and sustainable industrialization } \\
\text { and foster innovation }\end{array}$ \\
\hline Goal 10 & $\begin{array}{l}\text { Reduce inequality within and among } \\
\text { countries }\end{array}$ \\
\hline Goal 11 & $\begin{array}{l}\text { Make cities and human settlements } \\
\text { inclusive, safe, resilient and sustainable }\end{array}$ \\
\hline Goal 12 & $\begin{array}{l}\text { Ensure sustainable consumption and } \\
\text { production patterns }\end{array}$ \\
\hline Goal 13 & $\begin{array}{l}\text { Take urgent action to combat climate } \\
\text { change and its impacts* } \\
\text { * Acknowledging that the UNFCCC is the } \\
\text { primary international, intergovernmental } \\
\text { forum for negotiating the global response } \\
\text { to climate change. }\end{array}$ \\
\hline Goal 14 & $\begin{array}{l}\text { Conserve and sustainably use the oceans, } \\
\text { seas and marine resources for sustainable } \\
\text { development }\end{array}$ \\
\hline Goal 15 & $\begin{array}{l}\text { Protect, restore and promote sustainable } \\
\text { use of terrestrial ecosystems, sustainably } \\
\text { manage forests, combat desertification, } \\
\text { and halt and reverse land degradation and } \\
\text { halt biodiversity loss }\end{array}$ \\
\hline Goal 16 & $\begin{array}{l}\text { Promote peaceful and inclusive societies } \\
\text { for sustainable development, provide } \\
\text { access to justice for all and build effective, } \\
\text { accountable and inclusive institutions at all } \\
\text { levels }\end{array}$ \\
\hline Goal 17 & $\begin{array}{l}\text { Strengthen the means of implementation } \\
\text { and revitalize the global partnership for } \\
\text { sustainable development" }\end{array}$ \\
\hline
\end{tabular}




\section{The Model of Sustainable Age and Ageing: Three Theses, a Principle and the Suggested International Concept "SAI" which stands for "Sustainable Age and Ageing Initiative"}

This model and its three theses have been developed on the basis of present scientific material as well as long-lasting own practical experience in Salzburg and its connected development within the dynamic fields of gerontology and possible sustainable age and ageing. In the said model it is postulated that this way of successful sustainable age and ageing is rich in meaning, returns, knowledge, wisdom and possible societal participation on the part of mature persons, strengthening fairness, contacts and compassion. It can contribute greatly to individual self-development, regional peace as well as more fairness in various societies and, hopefully, the world-community in general. Therefore these three theses and the consequent recommendation of an internationally active initiative named SAI ("Sustainable Age and Ageing Initiative") would be constructed world-wide and, like the Red Cross, Red Crescent and Red Crystal, would be based on the seven principles and international humanitarian law, which deserve appreciative consideration and attention.

\subsection{First Thesis: Sustainable Societal Inclusion of Elderly People and Their Competencies is Essential and Relevant to the Whole of Society}

The generation 50+ is a most heterogeneous one. Several different generations went through completely diverse life-experiences and optional accesses to personal development, such as education, health, mobility, gender, having or not having a good financial background and so on, whereby old age and the processes of ageing varied widely amongst different people and age-groups alike. Those at the younger end of the spectrum of elderly persons are used to consuming more educational efforts than those at the older end of the spectrum usually were able to during their lifespan, while the health status of those at the younger end is often a better one than the health status of those at the older end. Therefore, it is assumed to be easier for people of the so-called younger "Baby Boomer Generations" to recognise their needs and generate the willingness to fulfil them; and thereby it is said that they have good optional access to information concerning sustainable issues. On the other hand, those at the older end of the elderly spectrum are a very large and growing societal population group - the group showing the strongest growth across Europe, representing and including also very many decedents, who have significant individual and social influence if they wish to use this. Many new and innovative ideas and projects can or could therefore be financed by interested and engaged mature people, willing to participate in further sustainable and societal topics and success. In addition, having various financial options also makes it easier for them to buy and invest in fairly produced products and to enjoy healthy organic food. - And fortunately, people out of all generations and societal backgrounds are nowadays quite open minded towards initiatives such as so-called 'green buying' and organic consuming which has become more and more a part of daily life during the last 15 to 20 years; their need, wish and ambition to act fairly unified them. - Therefore, it is postulated within this model that elderly people who are looking for fair and good sense in their lives can, furthermore, be activated to attractive sustainable fields of action, no matter whether they are from the elderly end of the spectrum, and have something to pass on, or from the middle-aged population of elderly people, or from the easy-going younger end of the spectrum, with or without financial scope.

Furthermore, there is another category within this large heterogeneous group of persons who are aged 50 and over ('50 plus'), which should always be considered and mentioned in particular: this is the category of very, very old women, living alone, who often live frugally because their pension or monthly income is extremely small. This group of either widowed or divorced women have learned to save whatever they can; often this is a life-long practice. Knitting, reusing clothing and recycling wherever is possible, helps them to save money. When talking with them about this way of life, at first they often speak with caution - they are sometimes even a little ashamed - but they turn out to be excellent champions in matters of sustainable living in everyday life. They know many methods of living frugally as well as helpful tips and "tricks". If they are told - in case they do not know already - that what they do and how they live is indeed very precious and wise in terms of sustainability and exactly what is needed to save our planet, they start to see it from a new perspective which makes them feel competent, personally important and even proud. In fact, this way of talking could be practised more often than it happens at present. It would be a very meaningful, lovely, appreciative and precious opportunity of coming together. Sharing experiences and knowledge between generations may thus help young and old alike - young and old learn how to do something well and easily, in a sustainable way and can even save money while this specific group of very old women finds new importance and meaning and new ways of passing on their precious sustainable wisdom. Moreover, they find new paths of gaining attention as well as new contacts and 
options to participate in society actively with joy and laughter (see theses three).

\section{Table 2. Focused Elderly Persons - Characteristics - Chances}

\begin{tabular}{|l|l|l|}
\hline $\begin{array}{l}\text { Focused } \\
\text { Persons }\end{array}$ & Characteristics & Chances \\
\hline Young old & $\begin{array}{l}\text { Good education, } \\
\text { easygoing }\end{array}$ & $\begin{array}{l}\text { Interested, } \\
\text { innovative }\end{array}$ \\
\hline $\begin{array}{l}\text { Financially } \\
\text { secure and } \\
\text { wealthy old }\end{array}$ & $\begin{array}{l}\text { Individuals with } \\
\text { options }\end{array}$ & $\begin{array}{l}\text { Can act and give } \\
\text { with sense and } \\
\text { meaning }\end{array}$ \\
\hline $\begin{array}{l}\text { Financially } \\
\text { poor elderly }\end{array}$ & $\begin{array}{l}\text { Often used to living } \\
\text { frugally }\end{array}$ & $\begin{array}{l}\text { Rich in } \\
\text { sustainable } \\
\text { methods, helpful } \\
\text { tips and "tricks" }\end{array}$ \\
\hline $\begin{array}{l}\text { Elder } \\
\text { employees }\end{array}$ & $\begin{array}{l}\text { Good with age- } \\
\text { friendly } \\
\text { surroundings }\end{array}$ & $\begin{array}{l}\text { Wise knowledge, } \\
\text { experience, good } \\
\text { atmosphere }\end{array}$ \\
\hline $\begin{array}{l}\text { 50+ Executive } \\
\text { staff }\end{array}$ & $\begin{array}{l}\text { Many options, } \\
\text { influence }\end{array}$ & $\begin{array}{l}\text { Scopes for } \\
\text { sustainability }\end{array}$ \\
\hline $\begin{array}{l}\text { "New" old } \\
\text { momen and } \\
\text { men }\end{array}$ & $\begin{array}{l}\text { Open for new ways } \\
\text { of ageing }\end{array}$ & $\begin{array}{l}\text { Try out, are open } \\
\text { to new } \\
\text { experiences, } \\
\text { engage in } \\
\text { travelling and } \\
\text { volunteering }\end{array}$ \\
\hline
\end{tabular}

Additionally, this huge diversity in very old age, whilst recognising financially secure people as well as wealthy or very rich individuals on the one hand and financially very poor old women on the other hand, can also be seen from the perspective of yet another differentiation in old age which refers to people 50 plus who have not yet retired: women and men who are still involved in the labour market. While several highly competent and well-paid people 50 plus are found in leading positions with great influence and significant scope for sustainable action, there are very many women and men among this age-group too who are unemployed, finding it very hard to get a job again. Several studies cite the issue of the unemployed aged over 50 as being relevant in the context of sustainability; it is therefore said to be important to keep as many elderly people employed as possible. The reality often remains otherwise, although it needs to be admitted that this handling does indeed vary between different European countries. While several explicit initiatives to integrate elderly people in the job market clearly led to a better development in Germany recently, the unemployment figures for older people in Austria remain high. Although hopeful Austrian initiatives of integration have been started, the unemployment rate for people 50 plus showed an increase of 17.2 per cent in July 2014, leading to strong words and impassioned discussions [1]. This is by no means solely the result of flagging economy, but mostly because (1) elderly people's competences are not recognised and (2) their needs in terms of labour conditions and specific requirements are not respected (see thesis two). Wherever the needs and specific learning conditions of elderly people have been well-considered, as several studies show us clearly, their labour output is good and moreover, they prove quite dependable for creating a good working climate. When we are looking at many different groups of elderly people and the list could be continued further extensively it is important to state that more and more lively, interested and active people in the 50 plus category could and should have an important place in society. Yet the reality is often quite different and needs to be constructively changed to ensure better inclusion of elderly people and good, as well as innovative, coexistence of generations and peoples in our common future on earth. Without any doubt, elder generations are changing continuously now; they are exploring life more and more from new perspectives. Whether they are lively 'young olds' or innovative 'old olds' - many of them find new ways of ageing, enjoying travelling, volunteering and appreciate a lot of what life has to offer. Will society in general, as well as decision- and policy-makers in particular, take advantage of this great chance and opportunity and support specific initiatives in this concern?

\subsection{Second Thesis: Lifelong Learning is a Chance for Sustainability and Mature Sustainable Living and Engagement}

Here it is postulated that lifelong learning can contribute essentially to good personal and professional development. Options for lifelong learning arise in many ways: seminars, lectures, talks, conferences, specific workshops, and more, offering opportunities for individual growth as well as concrete professional development of employees, volunteers or just interested people who want to gain new knowledge. It works best if connection is made with pre-existing know-how and connected feelings, and if further interests and enjoyment can be awakened. Learning, as we know from many studies, works very well in old age, whereas this main learning principle of getting enthused and therefore inspired should always be spotlighted [15]. Furthermore, it needs the consideration and guarantee of some very specific issues which one should basically keep an eye on when learning with people in the 50 plus age bracket. - Taking, for example, enthusiasm for learning, this is vital for success, and optimally should be developed during or through the learning process; results can be further improved if this is combined with personal relevance and concrete meaning. In contrast to younger learners, elderly people have more difficulty learning meaningless content. Moreover, it is essential to recognise that elderly people need more time for apperception and converting information. But if they 
are given the required time, they can even obtain better results than younger people. Since general know-how can then facilitate very good results. Furthermore, it should be remembered that it has been proven in many studies that in addition to reduced information processing, intellectual adjustment and flexibility also decrease with old age. Training can do much good in terms of building up and strengthening selected intellectual capacities, nevertheless, this is valid for such situations and competences and cannot be transferred automatically to other mental capacities, such as specific skills in daily life. - But the ability to learn in general, concentrating and maintaining one's general knowledge still persists with increasing but healthy age, and therefore offers numerous chances for sustainability training, initiatives and projects for sustainable development and the inclusion of elderly people in our society [6]. Hence, there is a plurality of options for saving this planet. Last but not least, learning depends heavily on former learning experiences, gender differences and needs, personality and the acquired educational profile as well as mobility - 'move and your spirit has the chance to do so too'. Consequently, an appropriate and specific didactic environment demands specific frames and constructive proceedings both for those who work with elderly persons and for elderly persons themselves. This should also be considered when working with (successful executive) staff aged over 50 and in particular with those who are engaged in the field of health-care and nursing. As many studies have shown, this is a sphere of action with an above-average risk of burn-out. Based on my personal experience as an executive-coach and supervisor in this field, and as a former employee in executive management, I suggest that team supervision, leadership- and executive-coaching are essential for the development of a good and sustainable process, in order to achieve sustainable goals within the facility as well as excellent and ongoing good working conditions. This applies to all age-groups within a team, working together in the most challenging circumstances, and is particularly true for personnel aged 50 plus, their well-being and success.

In summary, I postulate that considering these aspects can contribute much in moving our society towards sustainability and sustainable development in relation to state economies as well as everyday life. Enthusiasm is essential. Furthermore, leaning and working conditions and age-friendly surroundings are very important. Finally, societal pictures and thinking need to be changed urgently for the benefit of appreciative and respectful insights into age and ageing. The general increase in qualitative, high standing and challenging sustainable living, and with this the dignified societal integration of elderly people, could offer a wide range of interesting topics for lifelong learning and an immediate strong support for the cause of sustainability.

\subsection{Third Thesis: The Person-Centred Approach is Helpful in Supporting Sustainable Development and in Empowering Elderly People in Diverse Contexts}

To strengthen precious appreciation face to face with elderly people in various societies, to actively integrate them in community projects, to support them and help them, when they participate in major discussions by bringing in their own points of view and wishes are great signs of lively inclusion of elderly people within our society [5]. This engagement of mature persons can be signally and significantly used to empower grass-roots democracy with mature women and men and inspires people constructively through themselves. They organise and lead discussions to work on encouraging topics and search for results and therefore enact political participation in the best way and sense that can be imagined [10]. These efforts have been supported in many places because they align very well with scientific and practical community approaches that are well-known in several traditions of community development across the globe. Practical and scientific advocates have highlighted the importance of these approaches during the last twenty years as a consequence of and in accordance with societal needs. These approaches have thus contributed very constructively to an important aspect of sustainability: the active inclusion and integration of elderly people within their respective local communities. Almost at the same time environmental issues have gained more importance in our society, in relation to sustainable thinking and various sustainable opportunities. During the last fifteen years several sustainable initiatives and departments have been successfully established. - Therefore nowadays, no matter whether one considers elderly women and men who are still employed, and successful or those who are unemployed, or the selfemployed, or those who are retired (with or without additional [voluntary] jobs), sustainability-orientated thinking and behaving is very common and becoming more important on a daily basis. In walking their path of life, elderly people often involve themselves in community development and co-operation; they try to live as compassionately and to act as fairly as possible. Personal needs are thus recognised as something important in matters of dealing with it very carefully and just, since future generations should also be able to fulfil their own moderate needs, as various international papers about sustainability and sustainable development illustrate. The ability and willingness to hereby reflect inwardly with care and to act with personal honesty 
and integrity are both very important in this concern. This accords very well with person-centred approaches and associated humane principles of appreciation, acceptance, congruence and empathy connected to actualising potentials of power within every human being which enables to flourish and act positively within the normal course of life. - In fact, some scientific publications also illustrate this person-centred and respectful way of working with elderly people even though their numbers in Europe are still rather low [9] [2] [3] [4]. - Whether focusing on social and health issues, the importance of active participation of elderly people, or psychotherapy for mature women and men, or within the scope of nursing and supporting persons suffering from severe diseases like dementia and their carers - here and there the person-centred approach has proven to be very practicable and successful as a means of relieving, healing, empowering or working educationally with elderly people. It is therefore very useful to consider further supportive person-centred frameworks for elderly people and sometimes such frameworks are even essential for good and constructive outcomes.

One very important aspect of such frameworks is the support of those who provide care for others. Person-centred support can strengthen them according to their needs and in a biography-oriented and resource-focused way, whether they are family carers or other primary carers, nurses, socialworkers, home-helpers or another form of caregiver. This approach enables and engenders better ways of dealing with carer burdens and helps them to initiate constructive and healthy manners for themselves. Family carers who take care of relatives suffering from dementia show, as we know from studies, a significant higher risk than average, of developing dementia themselves. What they need is support through professionals such as nurses and homehelpers; free time for themselves and recreation; understanding and the chance to talk about their own suffering because of these burdens, which can be found in support groups. Person-centred offerings covering this range of concerns have proven to be very relieving for them and were therefore gladly and appreciatively taken up [4]. Such access to new relief, hope and laughter, of course, strengthens health and individual immune capacities. People find their very own 'golden hours' again along with enjoyment and happiness.

Meanwhile, there are very many important, inspiring and helpful opportunities for person- and client-centred perspectives in order to enlarge good and sustainable living: some family carers are effectively preventing their own risk of dementia by regularly attending self-help- and swimming-groups, others come together to talk about the construction of a building planned next door, yet others save or collect money in support of a project in Africa, while a community-centre-discussion group may meet to share knowledge and experiences with an invited support-group for diabetes. Members of all such groups empower each other and in turn often benefit others. And fun is almost always present in some form - some elderly women and men may decide spontaneously to meet briefly again and gather creatively, gardening together or sharing lovely organic recipes. It is doing them good. This is exactly the way in which sustainable educational programs work for elderly people. Laughter, talking, sharing, finding interesting news and receiving stimulating impressions as well as positive responses in an appreciative and humorous atmosphere; all these aspects help to lift the mood of (elderly) people and to strengthen their immune system. Endorphins are likely to be released in their body thereby and this makes it easier to feel new hope and empowerment [12]. Person-centred support is what it is all about: to find inspiring good within yourself and to do well for yourself; to explore; to find out what you like and who you are; to find ways to express ideas, thoughts, hopes - whatever it may be - and to be there for others too; sustainable housing and assisted living for elderly people; developing a new dancing class with others; or building up a grass-roots project and being involved in politics (of course one could also start a new small or bigger business in old age). In short, manifold options exist as long as you think about it - name it and it is probably realised already.

This is indeed a very large potential resource that should be considered, and considered with more consequence and planning! How much benefit of the survival of our planet could be achieved if more elderly women and men were to personally start to engage themselves in this aim with their specific competence and resource being offered. And indeed, many Western and European communities and local states have built up sustainable, supportive and inspiring initiatives within community development [13]: "Voluntary commitments and partnerships for sustainable development are multi-stakeholder initiatives voluntarily undertaken by [g]overnments, intergovernmental organizations, major groups and others that aim to contribute to the implementation of intergovernmentally agreed sustainable development goals and commitments...." $[18$, p. 2].

The question is whether this very positive sustainable movement could be picked up in a person-centred way within a still larger frame - the efficiency of some kind of think-tank for, and with action on the part of, elderly people, as well as their wisdom and engagement. This initiative would then consequently incorporate the aim of actively saving planet earth - before it is too late. And this is how I came to formulate the concept for the initiative called "SAI". 


\subsection{Deductive Principle and Practical Discussion - Implementing the Theoretical Principle and Model of Sustainable Age and Ageing and its Practical Initiative (SAI): Conception of a Red Cross-Crescent-Crystal Institution affiliated to the United Nations}

Several questions are raised by these issues: How could the potential of this wonderful, increasing and large group of elderly people worldwide be realised for common good? How could elderly persons actively and systematically apply their wisdom and use the opportunity to save the planet and to enable life for yet dying people across the planet? How can we take up these varied and multidimensional options for help, graceful knowledge and disposed action?

Let me state it very clear: The "Model of Sustainable Age and Ageing" indicates and postulates that people aged 50 and over - regardless of whether they are still employed, retired or living in any other way - have very great potential, in knowledge, experience and wisdom, about sustainability and sustainable development which they can and could offer and provide. It is proposed that their information, engagement and concrete actions for sustainability and sustainable development can and could do very much good, both regionally and internationally, and thereby contribute a huge force to save this planet and also save the lives of many people worldwide who are yet dying of hunger, thirst or are in other bad circumstances. The large potential of elderly people, which has been described in the three theses within this model, shows very clearly that there is an enormous capacity available amongst the elderly generations. It is also proposed that this power needs to be met immediately since many of them want to help and are aware of the risky situation of our planet. Furthermore it is proposed that these meaningful sustainable actions are also good for elderly helpers themselves and their participating would strengthen their own self-esteem, happiness and joy. Therefore it is suggested to directly implement an institution that can cover these demands internationally and effectively. Moreover this work and its results should be evaluated to test and check the efficiency of the theoretical model hereby stated.

While developing the "Model of Sustainable Age and Ageing" the author considered her own sustainable life, precious memories and professional roots as she herself also belongs to the population group aged over 50 . While she presently works in a private practice as executive coach, supervisor and psychotherapist, and is also engaged as a lecturer at the University of Salzburg occasionally, she has experienced three main strands of professional involvement before: Bahr was employed at the Austrian Red Cross Salzburg within the executive management, and several years earlier she worked as a research fellow at the European Centre for Social Welfare Policy and Research in Vienna, which is affiliated with the United Nations; and she was at the Berufsförderungsinstitut Salzburg, an institute for (continuing) education, where she trained people who wanted to start to work with elderly people. Now all of a sudden these experiences and relevant contact points seemed to relate very well when thinking of the conceptual framework concerning a sustainable initiative to fulfil her theoretical model. Based on the wisdom and experience of elderly people, the initiative should from the start be named "SAI" which simply is an abbreviation of "Sustainable Age and Ageing Initiative". It is a theory-deduced concept which should be implemented practically by means of an official institution and thereby demonstrating that the model is worthwhile in serving and promoting sustainability and sustainable development regionally and internationally through the support of people aged 50 and older.

Incidentally, 'sai' is an Italian word and means 'you know'. It comes from the word 'sapere', meaning 'knowledge' or 'to know' and therefore matches well with this initiative's claims: human engagement based on precious wisdom and competence. Humorously you could even express it that way too: SAI - you know - there is much to do - and the planet's clock is ticking - how about getting involved in the engagement to save lives and our planet in general?

It is hereby suggested that SAI should be an official and internationally adjusted Red Cross-Red Crescent-Red Crystal institution following the "Fundamental Principles - humanity, impartiality, neutrality, independence, voluntary service, unity, universality" which "reflect a certain discipline within the Red Cross and Red Crescent Movement" [7, homepage, p. 1]. - Moreover, this internationally adjusted - three in one - Red Cross-CrescentCrystal organisation should be economically and structurally incorporated to a local Red Cross, Red Crescent or Red Crystal organisation, but financed both regionally and internationally. Some employees and many volunteers should constructively be working together.

Furthermore, this internationally adjusted Red Cross-Crescent-Crystal organisation named SAI should be affiliated with the United Nations, since close contacts and budgets make it easier to develop and implement the right projects at the right time. Suitable departments within the United Nations and its specialised agencies to be considered for this purpose, include the World Health Organization (WHO), Food and Agriculture Organization (FAO), United Nations Educational, Scientific and Cultural Organization (UNESCO), World Bank Group 
(WBG) and the International Maritime Organization (IMO).

It is postulated that this internationally adjusted Red Cross-Crescent-Crystal institution called SAI and its associated elderly people can change the world for the better and would have the opportunity to start and maintain a regional and worldwide effective humane network of wisdom on behalf of elderly people and their wisdom. As always, it remains important also to consider an economic basis: in Austria, for example, we know the system of the 'Red-Cross-Schilling' whereby communities pay a certain amount of money to the local Red Cross. Its financial extent is oriented on the number of inhabitants in any particular region that may need support or rescue during a period of need or an emergency. To explain the word 'Schilling', this used to be the Austrian currency prior to the introduction of the Euro. As a result, in the "Model of Sustainable Age and Ageing" and its integrated Initiative SAI, every region or state in charge and supervision of tax money on the planet would pay a predetermined small amount of money to its local Red Cross, Crescent or Crystal organisation if they want to participate in this project and therefore be a partner of SAI. The amount should be scheduled and set according to a standardised system offered by SAI and the standard applied internationally. Furthermore if international partners would like to contribute their amount due, over a longer period it is suggested that their proposed budget-plan would have to be ratified by the state parliament. This would underpin long-term economic and economical budgets connected to regional and international engagement thus enabling constructive work and avoiding disagreements. - A highly specific SAIQuality-Handbook will need to be laid down at the beginning of the project, to incorporate all predefined processes and quality standards, strong regulations, hierarchies and audit descriptions that have to be applied regionally and worldwide to guarantee high quality standards for the SAI initiative. This is essential in order to prevent any possibility of corruption or unjust enrichment and to guarantee clear and transparent work for good.

Finally, in conclusion one could ask: Why did you draft Salzburg as the favoured place for the SIA Headquarters since it could be anywhere? Why not Vienna, New York, Sidney or Nairobi (UN) or Genf (ICRC)? - Firstly, because Salzburg is a city and small federal state in the middle of Europe and commonly associated with the heart of Europe. Secondly, because a very efficient infrastructure exists already and operates in relation to the Austrian Red Cross Salzburg, which is connected to many relevant fields of elderly care and areas of sustainable engagement. Moreover this organisation works to very high standards and quality levels. Thirdly, and this needs to be explained in rather more depth, because Salzburg is following its own particular path towards sustainability and as such may be considered inspiring and encouraging! In both the city and the state many successful and innovative industries and businesses are registered, including numerous locally-based organic farms. The city, as well as the state of Salzburg, are well-known for their beautiful nature and scenic attractions. Intact surroundings and the specialisation of organic farmers with marvellous products provide excellent locally and organically grown fruits and vegetables as well as delicious delicacies. This combination of local richness in nature, sustainable tourism, industry and successful economics generates regional wealth that guarantees constructive cash-flows in terms of tax incomes which enable a wide variety of sustainable, social, educational, medical and preventive-oriented programmes and opportunities for (elderly) citizens. The author is pleased to note that the city of Salzburg is also proud of the internationally famous Salzburg Festival which takes place in the city every summer and provides wonderful music.

\section{Conclusion}

Issues and opportunities for the good of old age and the process of ageing operate successfully when principles of sustainability and sustainable living are considered, respected and explicitly followed well. This applies to any topic relating to age and ageing, no matter whether the process of self-development of elderly people: casual meetings in the community; grassroots democracy; or professional disciplines, including, for instance, educational gerontology and continuing education, psychology, theology, sociology; architecture; building industry; general business administration; fair trade and business management. - The theoretical model and SIA hereby presented are designed to offer further opportunities in this context. The questions now arise: Will it be started? When? Who will volunteer? Is there anybody - helping? Interested? - To strengthen common fair lives?!

It is to be hoped that there are positive answers to these questions, since this theoretical model could help society change for the better. - SIA could save many lives by preventing inhumane and poor living environments whilst also contributing to our planet's recovery and a good, prosperous future.

Old age and ageing is sometimes called the 'autumn of life' and is also said to be as rich as nature. - Wonderful and strong, warm colours do us good by creating joy and thankfulness for a great harvest. Inner potentials become stronger and make it easier to help others with a glad heart; we rejoice in being blessed and in sharing this with others we sometimes are even led to further blessing. Hopefully we all will be able to see the richness of 
old age and ageing alike since with them come manifold options to develop the power of good within us and our societies. Bright affirming autumn colours do us good: as with autumn so with ageing. Sustainable wisdom and fairness may help us and our societies to be successful when seeking these harvests and achieve flowering. Thereby may we be exhilarated, laughing, dancing and celebrating as along with William Blake, who writes so expressively [16]:

“O Autumn, laden with fruit, and stain'd With the blood of the grape, pass not, but sit Beneath my shady roof; there thou may'st rest,

And tune thy jolly voice to my fresh pipe, And all the daughters of the year shall dance! Sing now the lusty song of fruits and flowers. The narrow bud opens her beauties to The sun, and love runs in her thrilling veins; Blossoms hang round the brows of Morning, and

Flourish down the bright cheek of modest Eve,

Till clust'ring Summer breaks forth into singing,

And feather'd clouds strew flowers round her head.

The spirit of the air live in the smells

Of fruit; and Joy, with pinions light, roves round

The gardens, or sits singing in the trees.

Thus sang the jolly Autumn as he sat,

Then rose, girded himself, and o'er the bleak

Hills fled from our sight; but left his golden load."

[16]

\section{Acknowledgements}

I would like to express my gratitude to Deborah and Alastair Harris, Surry, UK, for reading through my final paper and suggesting corrections concerning the translation which has been very helpful since English is not my native language.

\section{References}

[1] APA. (2014), Arbeitslosigkeit im Juli wieder gestiegen (translated meaning: Unemployment Increased Again in July); http://www.apa.at/News/6519627682/arbeitslosigke it-im-juli-wieder-gestiegen.html (Access Date: 30 August 2014).

[2] Bahr, C. (2006), Personorientierte Begegnung und Unterstützung demenzerkrankter Menschen (translated meaning: Person-Oriented Encounter and Support of People Suffering from Dementia), Psychologie in Österreich, Themenschwerpunkt Gerontopsychologie (translated meaning: Psychology in Austria, Topical Focus Gerontopsychology), 2006, 26, 3, pp. 201-207.

[3] Bahr, C. (2003), Gerontopsychotherapie (translated meaning: Psychotherapy with Elderly People) (pp. 138140), in G. Stumm, J. Wiltschko and W. Keil (Eds), Grundbegriffe der Personzentrierten und Focusingorientierten Psychotherapie und Beratung (translated meaning: Fundamental Terms of Person-Centred and Focusing-Oriented Psychotherapy and Counselling), Pfeiffer and Klett-Cotta: Stuttgart.

[4] Bahr, C. (1999), Entwicklungspsychologische Möglichkeiten im höheren Lebensalter am praktischen Beispiel des Sozial- und Gesundheitszentrums Gnigl (translated meaning: Prospects of Developmental Psychology in Old Age at the Example of the Social- and Health-Centre Gnigl), Person, Zeitschrift für Klientenzentrierte Psychotherapie und personzentrierte Ansätze (translated meaning: Person, Journal of ClientCentred Psychotherapy and Person-Centred Approaches), 1999, 3, 1, pp. 69-75.

[5] Bahr, C., Leichsenring, K. and Strümpel, C. (1996). Mitsprache älterer Menschen in Österreich (translated meaning: Co-Determination of Elderly People in Austria). Bundesministerium für Arbeit und Soziales (translated meaning: Federal Ministry for Labour and Social Affairs): Wien (Vienna).

[6] Cotman, C.W. and Engesser-Cesar, C. (2002), Exercise enhances and protects brain function, Exercise and Sport Sciences Reviews, 2002, 30, 2, pp. 75-79.

[7] International Committee of the Red Cross - ICRC. (2014), The Fundamental Principles of the Red Cross and Red Crescent; http://www.icrc.org/eng/resources/docum ents/p ublication/p0513.htm (Access Date: 28 August 2014).

[8] Global Footprint Network (2014), Earth Overshoot Day; http://www.footprintnetwork.org/en/index.php/gfn/pa ge/earth_overshoot_day/ (Access Date: 22 August 2014).

[9] Kitwood, T. (1997), Dementia Reconsidered: the Person Comes First. Open University Press: Buckingham.

[10] Leichsenring, K., Bahr, C. and Strümpel, C. (1999), The Politics of Old Age in Austria (pp. 65-82), in A. Walker and G. Naegele (Eds.), The Politics of Old Age in Europe. Open University Press: Buckingham, Philadelphia.

[12] Lewis, M., Haviland-Jones, J.M. and Feldman Barrett, L. (2008), (Eds.), Handbook of Emotions. $3^{\text {rd }}$ Edition. The Guilford Press: New York.

[13] Lotz, J. and MacIntyre, G. (2003), Sustainable People: a New Approach to Community Development. Cape Breton University Press: Sydney.

[14] OECD. (2008), Conclusion Sustainability Assessments. OECD Publishing; http://www.oecd-ilibr ary.org/environment/conducting-sustainability-assessmen ts_9789264047266-en;jsessionid $=4 \mathrm{hb} 3 \mathrm{fr} 5 \mathrm{rr} 9 \mathrm{rtv} . \mathrm{x}$-oecd-li ve-01 (Access Date: 26 August 2014). 
[15] Oswald, W.D., Gunzelmann, T., Rupprecht, R. and Hagen, B. (2006), Differential Effects of Single Versus Combined and Physical Training with Older Adults: the SimA Study in a 5-year Perspective, European Journal of Ageing, 2006, 3, 4, pp. 179-192.

[16] Shenandoah. (2014), Poem of the Week, "The Autumn" by William Blake (1783); http://shenandoahlite rary.org/blog/2013/10/to-autumn-by-william-blake-1783/ (Access Date: 27 August 2014).

[17] Stern, N. (2008), The Economics of Climate Change. Papers and Proceedings of the One Hundred Twentieth Annual Meeting of the American Economic Association (May), The American Economic Review, 2008, 98, 2, pp. $1-37$.

[18] UN-DESA. (2013), Voluntary Commitments and Partnerships for Sustainable Development, Sustainable Development in Action, Special Report, Issue 1, July 2013; http://sustainabledevelopment.un.org/content/documents/9 30Report\%20on\%20Voluntary\%20Commitments\%20and \%20Partnerships.pdf (Access Date: 26 August 2014).

[19] United Nations. (2014), Sustainable Development Platform. Outcome Document - Open Working Group on Sustainable Development Goals. Indroduction to the Proposal of the Open Working Group for Sustainable Development Goals; http://sustainabledevelopment.un.o rg/focussdgs.html or http://sustainabledevelopment.un.org content/documents/4518SDGs_FINAL_Proposal\%20of $\% 2$ 0OWG_19\%20July\%20at\%201320hrsver3.pdf (Access Date: 26 August 2014).

[20] UNEP. (2011), Green Economy Report. Introduction. New York: United Nations Environment Programme. [Partial Online] Introduction, 02.11.2011; http://www.unep.org/greeneconomy/Portals/88/documents/ ger/1.0_Introduction.pdf (Access Date: 26 August 2014). 